\title{
BUDGET RATCHETING IN GOVERNMENTAL BUDGETING: AN EMPIRICAL INVESTIGATION
}

\author{
Fauzan Misra \\ Andalas University, Indonesia \\ fauzanmisra@eb.unand.ac.id
}

\begin{abstract}
Previous literature has documented various aspects of behavior in the budgeting process. Behavioral problems that are often discussed include budgetary slack and opportunistic behavior that occur due to information asymmetry. However, there is little attention to behavioral problems in previous studies called ratcheting behavior. This study investigates such behavior in a governmental budgeting setting. Besides, this study extends by testing ratchet behavior when local government adopts a well-known budget control mechanism, called analysis on standardized expenditure. To accomplish this purpose, study participants role-played as the budget preparer on a government budgeting task. The experiment used a web-based instrument that involved 51 participants. Results showed that budget preparer engaged in a ratchet behavior when setting their budget. Furthermore, budget ratcheting did not occur when preparer using an analysis of standardized expenditure. However, this situation only remains for one year. In the next year, preparer engaged in a ratchet behavior, at a lower intention. These findings underscore the importance of analysis of standardized expenditure in a government budgeting process environment. As a practical contribution, these findings suggest that using and monitoring for the adoption of analysis on standardized expenditure should be maintained continuously.
\end{abstract}

\section{KEYWORDS:}

Budgeting; budget ratcheting; control; analysis of standardized expenditure 


\section{INTRODUCTION}

Various literature has documented various aspects of behavior in the budgeting process. Behavioral problems that are often discussed include budgetary slack and opportunistic behavior that occur due to agency problems and information asymmetry (such as Hobson, Mellon, \& Stevens, 2011; Rankin, Schwartz, \& Young, 2008; Abdullah \& Asmara, 2007; Ahn, Choi, Hwang, \& Hyeon, 2018). There are some behavioral problems that have not been studied yet in the previous studies, which is called ratcheting behavior. Ratcheting occurs when overspending at the last year's expenditures (actually exceeding those budgeted) lead to the greater absolute changes in current budgeted expenditures than underspending with a similar magnitude. For example, if there is overspending (actually higher than budgeted) of $5 \%$, it is likely that next year will be budgeted at least $105 \%$ than the previous year's budget. However, if the realization showed an underspending for $5 \%$, then next year's budget will not be reduced to $5 \%$.

Past performance certainly provides meaningful information that helps the superior to assess subordinates' abilities and performance potential (Banker, Darrough, Huang, \& Plehn-Dujowich, 2013). Indjejikian, Majejka and Schloetzer (2014) suggest that the use of current performance as a basis for determining future targets, often referred to as "ratcheting," is a common practice in many organizations. However, theoretical studies have argued that target ratcheting gives rise to the effort reduction problem referred to as the ratchet effect, the incentive for subordinates not to exert themselves to their full potential (Freixas, Guesnerie, \& Tirole, 1985; Weitzman, 1980; Ahn, et al., 2018).

Lee and Plummer's claim (2007) states that their research is the first empirical test of budget ratcheting in government indicates the limitation of the research on this topic in the government/public sector. Although this claim is not entirely valid as the discovery of Hercowitz and Strawczynsky (2002) also Ahn et al. (2018), who also examine ratcheting in the government, the statement that there is still limited research on ratcheting in the public sector is acceptable. Cumulatively, both in the private and the public sector, among the previous studies of budget ratcheting that are still limited are Leone and Rock (2002), Kim and Yang (2012) also Bouwens and Kroos (2011) who did it in the private sector settings, while Lee and Plummer (2007) also Hercowitz and Strawczynsky (2002) in the public sector. Lee and Plummer analyzed ratcheting operational costs at district schools in Texas, while Hercowitz and Strawczynsky (2002) conducted a budget ratcheting analysis by looking at the economic cycle in Organisation for Economic Co-operation and Development (OECD) countries. Meanwhile, Ahn et al. (2018) investigate ratcheting intensity in the State-Owned Enterprises in Korea. Since the limitation of research in budget ratcheting, especially in the context of government, this study wants to fill in this gap by testing whether ratcheting also occurs in local government (public sector) budgeting in Indonesia. Similar with Lee and Plummer (2007), this study also focused on the analysis of operational expenditure and operational sub-expenditure.

Lee and Plummer (2007) assert that the phenomenon of budget ratcheting and its implications is different among private and public sector. Budget ratcheting in the government environment is ratcheting, which involves asymmetric growth in expenditure while ratcheting in the private sector focuses on asymmetric growth in income (earnings). Leone and Rock (2002) associate budgeting ratcheting with the choice of managerial dis- 
cretionary accruals, while Bouwens and Kroos (2011) examine budgeting ratcheting concerning sales targets in the fourth quarter of the company's business units. In a similar vein, Kim and Yang (2012) use data on earnings-per-share (EPS) targets, the most common performance measure in executive bonus plans, and show that EPS target increases are significantly associated with prior-year favorable performance relative to the target. The private company will face obstacles in the form of penalties for increased spending, which is not accompanied by an increase in performance in the capital market.

However, in the government sector or the public sector, penalties like this do not exist. There is no formal penalty for overspending or an award for underspending. Therefore, it can be predicted that administrators and government employees have incentives and opportunities to increase or expand their budgets, and this is the subject of constraints that are weaker to spending than the case in the private sector. Based on this reason, it is suspected that the government budget is ratchet. Then, ratcheting to the private sector associated with profit-based bonuses recognizes management actions as profitable actions for companies. This situation indicates that the ratcheting budget benefits the stock trader. Different things occur in the public sector; the budget ratcheting phenomena may expense the public interest.

Lee and Plummer (2007) find that budget ratcheting occurs when controls are considered weak. They use several instruments of control over government expenditure (district school), both direct control such as Tax and Expenditure Limitation (TELs), accounting regulations and budget reporting, and indirect control through the media (newspapers, television, and radio). In the context of controlling government spending, Giroux and Shields (1993) use accounting controls and political competition. In this study, related to the phenomenon of budget ratcheting and control, the existence of Analysis of Standardized Expenditure (ASE) is used as a control mechanism over budget ratcheting behavior.

The term ratcheting in government budgeting was first introduced by Weitzman (1980). Weitzman (1980) developed a model where economic planners used current performance as a partial basis to set performance targets for the next period, a trend which was then referred to as a "ratchet principle". For government entities, "performance" is measured using expenditures needed to reach a certain level of goods or services, with lower expenditures representing better performance. Ratcheting is closely related to the determination of performance targets both revenue targets and expenditure targets when determining future targets using past performance as a basis (Aranda, Arellano, \& Davila, 2014).

Two models explain the fiscal behavior of local governments related to the phenomenon of budget ratcheting for the government's spending. First, the median voter model, which implies that government employees will act for the best interest of the voters, and consequently will determine expenditure based on voter preferences (Black, 1958, Lee \& Plummer, 2007). Second the Leviathan Model which implies that local governments have monopoly power and run budgets to maximize the interests of bureaucrats (Brennan \& Buchanan, 1977, 1978).

Previous research has provided empirical evidence that ratcheting from budgeted income occurs in the private sector, and the evidence implies that ratcheting is rational and profitable to companies (Leone \& Rock, 2002). However, budget ratcheting in government is different from what happens in the private sector (Lee \& Plummer, 2007). The first sector focuses on earnings, while 
the second emphasizes ratcheting from the expenditure side. Then, the implications of ratcheting in the public/government sector are not necessarily beneficial to constituents or voters. Furthermore, Indjejikian et al. (2014) suggest that target ratcheting has an adverse effect on incentives because selfinterested managers may withhold effort in the current period to avoid higher targets in the future. According to the importance of control and suspected of the occurrence of budget ratcheting, the problems in the study are formulated as follows:

1. Does budget ratcheting occur in local government operational expenditure?

2. Is the budget ratcheting trend smaller in the government with more effective expenditure controls?

Since there is a budget ceiling in government budgeting that cannot be skipped, testing using secondary data or surveys is not possible to be done. Therefore, this study was conducted using the experimental method by creating an overspending scenario completing the underspending conditions. This is based on the assumption that $100 \%$ expenditure achievement may actually still require an additional budget set forth in the amended budget (Anggaran Pendapatan dan Belanja Daerah-Perubahan, APBD-P).

Using the Weitzman Ratcheting model (1980) and modified with the model used in Lee and Plummer (2007), this study aims to investigate the occurrence of asymmteric budget ratcheting in local governments empirically. Asymmetric ratcheting is a phenomenon in which an increase in the budget due to overspending, and a decrease in the budget due to underspending, are unequal (Lee \& Plummer, 2007). This study also aims to provide empirical evidence about the effect of the control mechanism on the occurrence of budget ratcheting patterns.

This study provides several contributions to the research on local governments' budgeting. First, this study complements empirical studies to examine budget ratcheting in the public/government sector, which is still limited. Second, according to the issue of control and monitoring has been more prevalent in the private sector, this study fills this gap by examining the impact of controls on government operational budgets. Third, this study complements existing government budgeting studies that are more focused on discussing opportunistic behavior and budgetary slack.

Target Setting is at the core of planning and budgeting in an organization. Setting accurate targets is important for resource allocation and coordination (Leone \& Rock, 2002). Targets are defined as the expected level of performance and are included in planning documents such as the budget. Coordination, resource allocation, and performance evaluation are organizational activities that are closely related to planning and targeting. In budgeting, the target sets at least the revenue and expenditure target. In the Indonesian government, there is also a financing target in addition to revenue and expenditure targets. These targets are formally included in the government budget, both the state budget (Anggaran Pendapatan dan Belanja Negara, APBN) and the local governments' budget (Anggaran Pendapatan dan Belanja Daerah, APBD). At the end of the year, the achievement of this target will be delivered in the financial statements and government performance reports as stipulated in Government Regulation Number 8 of 2006 concerning Government's Financial and Performance Reporting.

\section{Government Budgeting in Indonesia}

The budget is the primary tool of the government to carry out all obligations, promises, and policies into concrete plans and it is integrated to what actions will be taken, what 
results will be achieved, at what cost and who will pay these costs (Dobell \& Ulrich, 2002). Meanwhile, Freeman and Shoulders (2003) state that the stipulated budget can be seen as a performance contract between the legislature and the executive. According to Rubin (1993), public budgeting is a reflection of the relative strengths of various budget actors who have different interests or preferences on-budget outcomes. The lack of funds owned by the government is the reason why budgeting is the most critical mechanism for the allocation of resources.

The implementation of regional autonomy in Indonesia is inseparable from the paradigm shift in regional management and budgeting. Performance budgeting is a concept in budgeting that explains the link between resource allocation and the achievement of measurable results. Performance-based budgeting began to be implemented in Indonesia based on Government Regulation Number 105 of 2000 and Ministry of Home Affairs Decree Number 29 of 2002 in the 2003 or 2004 fiscal year. Performance budgets encourage the participation of stakeholders so that the goal of achieving results is following public needs.

The process of budgeting in performance budgeting starts from the organization units in the local government, through a budget proposal document called the Local Government Organization Unit Budget (Rencana Kerja dan Anggaran-Organisasi Perangkat Daerah, RKA-OPD). The local government budget team then examines the RKA-SKPD (Rencana Kerja dan Anggaran-Satuan Kerja Perangkat Daerah) to assess its feasibility (based on the urgency and availability of funds) accommodated in the Local Government Budget Plan (Rancangan Anggaran Pendapatan Belanja Daerah, RAPBD), which will be submitted to the legislature. The RAPBD is then studied by the legislative budget committee and responded by all com- missions and factions in the budget discussion.

\section{Controlling Government Expenditures}

Although local governments are given the authority to prepare budgets according to local needs, there are some restrictions in the form of regulations on the amount of expenditure/expenditure they can spend. This is done to make the value for money can be adequately realized. One form of restrictions imposed is that local governments must follow the guidance of the analysis of expenditure standards in the budgeting process.

Related to the explanation above, Law Number 32 of 2004 emphasized the need for a Performance-Based Budget (PBB). The PBB approach emphasizes accountability not only to the allocation of inputs but also considers outputs and outcomes. PBB can be used to measure performance in assessing the success or failure of implementing activities/ programs/policies following the stated goals and tasks. For the performance measurement purpose, it is essential to establish a performance indicator first, namely, input indicators in the form of funds, resources, and work methods. It is necessary to assess its fairness so that that input can be accurately informed in a budget. In assessing the fairness of inputs and outputs, the role of the ASE is required. ASE is the assessment of the reasonableness of the workload and costs used to carry out an activity. ASE is one of the main elements for performance-based budgeting to achieve economic, efficient, and effective financial management (application of value for money concept). ASE is assessed as a formal link between the input issued and the output and outcome achieved. This encourages the local government to always pay attention to every rupiah earned and used.

Furthermore, the significance of the ASE is reinforced again in Government Regulation 
Number 58 of 2005 concerning the Local Government's Financial Management. The regulation then elaborated again in the Minister of Home Affairs Regulation Number 13 of 2006 concerning Guidelines for Local Government's Financial Management (as amended by Number 59 of 2007 and Number 21 of 2011). In these regulations, it is always suggested that ASE is one of the main instruments in performance-based budgeting. Although ASE is an essential instrument in the local budgeting process, not all regions have ASE. This study assumed that the existence of ASE is considered as a stronger form of control over local government expenditure.

\section{Fiscal Behavior of the Government}

Ungureanu and Iancu (2012) identify that there are several behavioral models in budget-maximization theory, including the Niskanen Model of bureaucratic behavior and the Leviathan Model, which explain the differentiation between bureaucrats and politicians behavior in government budgeting processes. Meanwhile, Wills (1995) states that two models may explain the determination of government expenditure budget, namely the agenda-setter model and the median voter model. On the other hand, Lee and Plummer (2007) imply there are two theories of government behavior about budgeting with different perspectives from each other, namely the Median Voter Model and the Leviathan Model. Lee and Plummer (2007) state that the two models they convey are relevant to the research that wants to test whether ratcheting on expenditure occurs in the public sector. In this regard, this study refers to the classification presented by Lee and Plummer (2007).

The median voter model implies that government officials will act in the best interests of constituents and determine budgets based on their preferences (Black, 1958; Bowen,
1943; Gerber \& Lewis, 2004). Ideally, the government should provide goods and services at the level desired by the constituents at the lowest cost. This explanation is consistent with the principles of efficiency, effectiveness, and economy (value for money concept) in government budgeting. This model implies that the government apparatus will make adjustments to the next year's budget fairly and appropriately related to overspending and underspending, without a priori reasons why overspending should be emphasized more than underspending.

However, empirical evidence shows that government spending is not correspondence to the level of service desired by voters (Dye \& McGuire, 1997; McGuire, 1999; Romer, 2004). In fact, the economic literature, in general, supports the Leviathan model to explain government behavior related to budgeting, which states that local governments have monopoly power and run budgets to maximize the interests of bureaucrats (Brennan \& Buchanan, 1977, 1978,). As a result, government spending is more influenced by the bureaucrat's utility function than the median voter. Government administrators have incentives to maximize their budgets to get excess consumption perquisite, "over-produce" public goods, make less effort, and spend resources on less essential activities that produce personal enjoyment (Giroux \& Shields, 1993). For almost all employees in individual government institutions, a larger budget can increase their job security if it causes legislators and constituents to perceive that the services of these institutions are relatively essential. These particular institutions are rarely subject to budget deduction by the legislature, and even if they are subject to deduction, the number is small. It will only affect a small number of employees. Giroux and Shields (1993) argue that government administrators also try to maximize their budgets to get financial slack. 
It should also be noted that government administrators may increase the budget to improve services to the public or their constituents. They try to increase the budget so that the goods and services they provide to the constituents or voters based on their interest. If the budget ratcheting is done in this situation, it can be said that budgeting expenditure is allocate and practicing to meet social desirability. To capture this phenomenon, Lee and Plummer (2007) conducted a sensitivity analysis by examining the relationship between budget ratcheting and student academic performance as a representation of socially desirable outcomes.

\section{Ratcheting in Budgeted Expenditure}

The use of performance currently is used as a partial basis for setting future targets that have almost become a universal feature of economic planning (Weitzman, 1980). This principle came to be known as the "ratched principle". Weitzman (1980) developed a model in which economic planners used current period performance as a basis for setting targeted future performance. For government entities, "performance" is measured using the amount of expenditure/ expenditure needed to reach a certain level of public goods or services. The lower the expenditure is, the better of performance grade. By using $\mathrm{Bt}$ notation to represent budgeted expenditure in year $t$, and At to represent actual expenditure, the Weitzman (1980) model applied to the public sector predicts:

$\mathrm{Bt}-\mathrm{Bt}-1=\delta+\lambda(\mathrm{At}-1-\mathrm{Bt}-1)$

This equation can be interpreted that the current year's expenditure budget depends on, in part, the variance of last year's budget (through the adjustment coefficient $\lambda$ ), and independent growth $\delta$. Weitzman (1980) assumes that, at a constant level of government service, government administrators will be rewarded if the actual expenditure is lower than budgeted expenditure $(\mathrm{At}<\mathrm{Bt})$. This provides an incentive for government administrators to reduce the actual budget. This model predicts that administrators face a trade-off between current and future rewards. Rewards of current performance (At$1<\mathrm{Bt}-1)$ must be weighed against the costs that arise for future performance sacrifices. Due to the adjustment coefficient $\lambda$, better current performance will reduce $\mathrm{Bt}$ in the coming period, and this makes it difficult for administrators to get rewards in the future. Weitzman (1980) also shows that the future cost of good current performance will increase when $\lambda$ increases.

The trade-off between current and future rewards in the Weitzman model arises because the government apparatus has an incentive to reduce actual expenditure so that At-1 < Bt-1, which results in downward pressure on budgeted future expenditure. Lee and Plummer (2007) assume that government administrators also face relatively strong personal incentives to expand their budgets. The absence or limitation of rewards for minimized expenditure, along with incentives to increase the budget, provides an environment that they predict to form an asymmetrical ratcheting pattern. Specifically, they predict that government administrators will make greater adjustments to their budgets to reflect last year's overspending (At-1> Bt-1) than if underspending occurs. This explanation is the reason Lee and Plummer modified the equation in the Weitzman model to show differential adjustments depending on the sign of variance. The modification equation becomes:

$$
\mathrm{B}_{\mathrm{t}}-\mathrm{B}_{\mathrm{t}-1}=\delta+\lambda^{+}\left(\mathrm{A}_{\mathrm{t}-1}-\mathrm{B}_{\mathrm{t}-1}\right)+\lambda-\mathrm{U}_{\mathrm{t}}{ }^{*}\left(\mathrm{~A}_{\mathrm{t}-1}-\mathrm{B}_{\mathrm{t}-1}\right)
$$

In this case, $U_{t}$ is equal to 1 if the budgeted expenditure exceeds the actual expenditure (underspending), and $\mathrm{o}$ if the opposite. $\lambda+$ is the adjustment coefficient for overspending $\left(\mathrm{A}_{\mathrm{t}}-1>\mathrm{B}_{\mathrm{t}}-1\right)$ and $\lambda$ - is the 
differential coefficient for underspending $\left(A_{t}\right.$ $\left.-1<\mathrm{B}_{\mathrm{t}}-1\right)$. The second sum of the coefficients $(\lambda++\lambda-)$ is the adjustment coefficient for underspending. If government administrators respond more to overspending than to underspending, then $\lambda$ - will be negative. Lee and Plummer (2007) refer to $\lambda$ - as the coefficient of ratcheting.

Lee and Plummer (2007) find that budget control mechanism provided by district local government influence the magnitude of budget ratcheting. They find that budget ratcheting is more pronounced when controls on government spending are likely to be weaker. Ahn et al. (2018) find that ratcheting intensity is substantially greater (lower) for target-setting methods that have utilized limited (plenty of) information on past performance and that the ratchet effect increases with ratcheting intensity.

Based on an explanation of the budgeting process, the upper limits on government expenditure, fiscal behavior of government budgeting and budget ratcheting to local governments, the hypothesis of this study are:

H1: There is a budget ratcheting in government operational spending.

H2: Ratcheting tends to occur (more pronounce) in local governments with weaker budget control

\section{RESEARCH METHOD}

This study uses a laboratory experimental approach. Participants act as employees in the planning and budgeting section of the Regional Apparatus Organization (RAO), who are in charge of preparing the annual budget. The budget line is focused on the operational budget. They were asked to propose a 4-year budget based on the realization of the previous year. From the realization of the previous year, participants received two years with an overspending condition and another two years in an underspending condition. To control the confounding effect of information about the realization of expenditure in the previous year, all participants received the same information. Then, some participants will get the treatment of a proper budget control through the ASE instrument, while other participants get conditions without adequate control (have no ASE).

The participants of this study were planning and budgeting staff at the local government in Sumatera who attended the Workshop at Andalas University, both conducted by the Center for Financial and Development Studies (Pusat Studi Keuangan dan Pembangunan, PSKP) and the Center for Accounting and State Finance Studies (Pusat Studi Akuntansi dan Keuangan Negara, PSAKN). PSKP is annually trusted by the Directorate General of Fiscal Balance (Direktorat Jenderal Perimbangan Keuangan, DJPK) of the Ministry of Finance of the Republic of Indonesia to carry out various education and training, including planning and budgeting. Likewise, PSAKN also carries out similar activities in several activities in 1 year. Participants were recruited through the direct notification, which was followed up by repeated notification via Whatsapp to each prospective participant. Participants then completing experimental tasks online through a web-based instrument by $\log$ in to the system after stating their willingness to participate.

This study uses the basic model of Weitzman's (1980) ratcheting budget modified by Lee and Plummer (2007). By doing the modification, this model is able to show a differential adjustment in government expenditure by looking at the sign of variance. Meanwhile, to see the difference in the occurrence of budget ratcheting in the regions with a stronger control mechanism, crosssectional testing will be conducted between samples. Samples that have ASE are consi- 
dered regions with stronger control (coded 1), and on the contrary, regions that do not have ASE are considered to have weaker budget control (coded o). By coding the two categories (dummy variables), model testing will be done separately for each local government category.

\section{RESULT AND DISCUSSION}

The participants of this study start by opening the assignment's website and logging in using the specified username and password. Fiftyeight participants were completing the assigned tasks, and the data was recorded into the system. Based on the manipulation check test, 7 participants failed to give an appropriate response, so the data was not used. This resulted in 51 observations that can be used. Before taking data to the participants, a pilot test was conducted involving 30 undergraduate students of the Department of Accounting, Faculty of Economics, Andalas University who took Government Accounting courses. Of the 51 participants, 21 were male $(41.17 \%)$, and 30 were female (58.83\%). The average work experience of the participants was 77 months or 5.45 years, with an average age of 38.61 years.

Statistical testing was carried out for three years of budgeting. Descriptive statistics and the results of the paired-sample t-test are presented in Table 1.

Table 1. $t$-test for the 1st year (baseline)

\begin{tabular}{lcc}
\hline & Controlled & Uncontrolled \\
\hline Underspending & -2.04 & -2.36 \\
\hline t-test & $\mathrm{t}=0.458 ; p=0.651$ \\
\hline Overspending & $\mathbf{7 . 0 0}$ & $\mathbf{6 . 6 4}$ \\
\hline $\mathrm{t}$-test & $\mathrm{t}=0.547 ; p=0.589$ \\
\hline Total & $\mathbf{4 . 9 6}$ & $\mathbf{4 . 2 8}$ \\
\hline $\mathrm{t}$-test & $\mathrm{t}=0.764 ; p=0.452$ \\
\hline
\end{tabular}

Hypothesis 1 predicts that ratcheting occurs in local government budgeting. From table 1, it can be seen that in responding to the underspending of the previous year with an average of $10 \%$, the proposed budget variance from the previous target for regions planning ASE was -2.04\%, while the comparison that would not implement ASE was $2.36 \%$ of the previous year's target amount (100\% condition). A variance of $-2.04 \%$ indicates that in the condition of underspending $10 \%$, the apparatus planner proposes a budget of $100 \%$ minus $2.04 \%$ or $97.96 \%$ of the previous year target. This figure shows that even though the budget experienced underspending up to $10 \%$, the proposed budget still approached the target to know beforehand. With the same interpretation, another proposer proposes $97.64 \%$ of the previous year's target of only $90 \%$. This result implies that the budget proposer is not "willing" to reduce it to $10 \%$ following the realization of the previous year. The t-test results in this underspending condition showed no difference between the two groups treatment $(\mathrm{t}=$ $0.458, p=0.651$ ).

Furthermore, in overspending conditions, it can be seen that the budget variance of each group is $7 \%$ and $6.64 \%$, respectively. The $7 \%$ variance meant that the budget proposer proposed a budget of $7 \%$ higher than the previous year's target when there was overspending of $10 \%$, and the comparison proposed an increase of $6.64 \%$. Both groups proposed a budget that was getting closer to realization and did not want to propose the same amount as the previous year, even though it did not exactly reach a $10 \%$ increase. The t-test results in this overspending condition also showed no difference between groups $(t=0.547, p=0.589)$.

Finally, table 1 shows that in total, the proposed budget variance is 4.96 and 4.28 . Ttest results for the total budget conditions also showed there was no significant differrence between groups $(t=0.764, p=0.452)$. The overall test results showed that there 
was a smaller variance when the previous year's underspending occurred than when there was overspending. These results indicated the occurrence of budget ratcheting. The study also showed that there were no significant differences between groups. This finding implies that the occurrence of ratcheting covered all local governments. Thus, hypothesis 1 is supported.

Hypothesis 2 predicts that the probability of the occurrence of ratcheting is higher in local governments with weak budget control (without ASE) than local governments with better control (through the application of ASE). The results of the t-test in the second year as the first year of ASE implementation in some local governments as indicated by the manipulation of the presence or absence of ASE are presented in Table 2.

Table 2. t-test for the 2 nd years (first-time ASE Adoption)

\begin{tabular}{lcc}
\hline & Controlled & Uncontrolled \\
\hline Underspending & -3.44 & -0.96 \\
\hline $\mathrm{t}$-test & $\mathrm{t}=6.619 ; p=0.000$ \\
\hline Overspending & $\mathbf{3 . 4 8}$ & $\mathbf{6 . 4 4}$ \\
\hline $\mathrm{t}$-test & $\mathrm{t}=5.220 ; p=0.000$ \\
\hline Total & $\mathbf{0 . 0 4}$ & $\mathbf{5 . 4 8}$ \\
\hline $\mathrm{t}$-test & $\mathrm{t}=8.019 ; p=0.000$ \\
\hline
\end{tabular}

As can be seen in Table 2, in responding to the underspending of the previous year with an average of $10 \%$, the proposed budget variance from the previous target for regions applying ASE for the first time was $-3.44 \%$, while the comparison of regions not applying ASE was -0.96\%. This result can be interpreted that when the previous year, there was an underspending of $10 \%$, regions with ASE proposed a budget of $96.56 \%$ from the previous year's budget. In comparison, regions without ASE proposed 99.04\%. The ttest results in this underspending condition showed that there were differences between groups $(t=6.619, p=0,000)$.
Likewise, in the overspending condition, it can be seen that the budget variance of each group is $3.48 \%$ and $6.44 \%$, respectively. This result meant that when there was overspending of $10 \%$ in the previous year, regions implementing the ASE incited expenditure proposals that were closer to the $100 \%$ target of $103.48 \%$ of the previous year's budget than those without the ASE who proposed $106.44 \%$ of the previous year's budget. The ttest results in this overspending condition also showed a difference between these two groups $(t=5.220, p=0.000)$. Furthermore, Table 2 showed that in total, the proposed budget variance was $0.04 \%$ in the group with ASE implementation compared to 5.48 in the non-ASE group. T-test results for the total budget conditions also showed that there were significant differences between the two groups $(\mathrm{t}=8.019, \mathrm{p}=0.000)$. Overall test results showed that there was a smaller variance when there was underspending the previous year than when there was overspending, especially for regions without ASE. The existence of significant differences between groups shows that the existence of ASE, as a budget control tool, influences the occurrence of budget ratcheting. In other words, the tendency for the occurrence of ratcheting is higher (more pronounced) in areas without ASE. This result indicates support for hypothesis 2 .

Table 3. $t$-test for the 3rd year (Second year of ASE Adoption)

\begin{tabular}{lcc}
\hline & Controlled & Uncontrolled \\
\hline Underspending & -2.00 & -2.11 \\
\hline $\mathrm{t}$-test & $\mathrm{t}=0.259 ; p=0.780$ \\
\hline Overspending & $\mathbf{5 . 9 2}$ & $\mathbf{6 . 8 0}$ \\
\hline $\mathrm{t}$-test & $\mathrm{t}=1.178 ; p=0.250$ \\
\hline Total & $\mathbf{3 . 9 6}$ & $\mathbf{4 . 6 8}$ \\
\hline t-test & $\mathrm{t}=2.883 ; p=0.132$ \\
\hline
\end{tabular}

A sustainability test for the effectiveness of ASE as a control tool was also carried out. The results of testing in the third year as the 
second year of ASE implementation are presented in Table 3. From Table 3, it can be seen that in the underspending condition, there is no difference in the proposed budget variance between groups that apply ASE or not. The same thing happens in the overspending and total data even though the data shows that the variance in the underspending condition is smaller than in the overspending condition.

This unequal variance shows the number of proposals getting closer to $100 \%$, which means that there is ratcheting. Based on the conditions of implementing ASE, ratcheting is seen more clearly in conditions without ASE than in the condition of ASE. This result implies that ASE still influences budgeting practices in the next year. However, statistically, this effect is no longer as significant as in the first year, the ASE was firstly implemented $(t=2.883 ; p=0.132)$.

In addition to the budgetary slacks issue, budget ratcheting is also a behavioral issue that needs attention in the budgeting process. Ratcheting occurs if there is asymmetric variance in the budget proposal under conditions of underspending and overspending with the same magnitude. This study aims to examine the occurrence of ratcheting in the budgeting process in local government and the impact of the adoption of the ASE as one of the budget control tools from preparation to implementation.

The results of hypothesis testing indicated that there was ratcheting in the budgeting by the local government. This means that the government has a tendency to keep the amount of the budget close to the target amount of the previous year if it experiences underspending and increases the budget close to realization when overspending occurs. In the case tested in this study, when underspending and overspending occur at a magnitude of $10 \%$, the budget proposer pro- poses the next year's budget with a pattern of not following a $10 \%$ variance when underspending occurs and will propose a budget approaching a $10 \%$ variance if experiencing overspending in the previous year. This asymmetrical variance shows the occurrence of ratcheting practices in the budget proposal. The findings of this study are consistent with Lee and Plummer (2007), who find ratcheting behavior in budgeting in district schools in the state of Texas.

This budget ratcheting practice is expected to be minimized or mitigated through the implementation of the ASE. The test results show that ASE is effective in minimizing the behavior of this ratchet. Areas that implement ASE show a much lower rate of ratcheting than those shown by regions without ASE. This finding is also in line with the findings of Lee and Plummer (2007), which show the effectiveness of control mechanisms applied in government budgeting. It is also consistent with Ahn et al. (2018) who find that ratcheting intensity is substantially lower for target setting method that has utilized plenty (in comparison with limited) of information on past performance. They consider that target setting methods as ratchet control mechanism.

The findings of this study suggest the need for budget control, starting from the preparation until the implementation and reporting stages. ASE, as a control tool in local government budgeting, can play a strategic role in controlling ratchet behavior. This finding implies the importance of local governments in preparing this instrument. Besides, it needs to be a concern that the implementation of ASE from year to year should be accompanied by continuing monitoring from all of the stakeholders. As found in this study, although not hypothesized, ratcheting behavior re-emerges with almost equal magnitude in areas that have applied ASE compared to regions that do not apply ASE. 


\section{CONCLUSION}

This study aims to examine the occurrence of budget ratcheting in local government budgeting processes. By involving budget makers in local governments in Sumatera, the results of this study show that ratcheting behavior occurred in the preparation of local government budgets. Then, by applying the ASE, such behavior can be minimized. This study indicates that regions that apply ASE show a much smaller level of budget ratcheting than regions without ASE.

These findings imply that the ASE is critical when the local government prepare its budget. The existence of budgeting instruments such as ASE can control the tendency to ratchet behavior. As such, it is recommended for local governments to have and apply an ASE, not only to meet the requirements of a performance-based budget framework but also as a control mechanism in government budgeting processes.

Several limitations can be identified in this study. First, this study uses conditions that give rise to overspending conditions that are not found in government budgeting due to budget ceiling limits. Second, the time span of testing the effectiveness of ASE implementation is limited to one year after the firsttime adoption. Future study needs to consider these two crucial factors. Future study may also test the effectiveness the other form of control by investigating the influence of final budget authorities (superior or subordinate), the arrangement of the past performance data, and modification of target setting methods.

\section{REFERENCES}

Abdullah, S., \& Asmara, J. A. (2007). Perilaku oportunistik legislatif dalam penganggaran daerah: bukti empiris atas aplikasi agency theory di sektor publik. The Indonesian Journal of Accounting Research, 1O(1). doi: doi.org/10.33312/ijar.165

Ahn, T. S., Choi, Y. S., Hwang, I., \& Hyeon, J. (2018). The effect of information asymmetry and participative target setting on target ratcheting and incentives. Public Performance and Management Review, 41(3), 239469.

Aranda, C., Arellano, J., \& Davila, A. (2014). Ratcheting and the role of elative target setting. The Accounting Review, 89(4), 1197-1226. doi: 10.2308/accr50733

Banker, R. D., Darrough, M. N., Huang, R., \& Plehn-Dujowich, J. M. (2013). The relation between CEO compensation and past performance. The Accounting Review, 88(1), 1-30. doi: 10.2308/accr-50274

Black, D. (1958). The theory of committees and elections. Cambridge, U.K.: Cambridge University Press.

Bouwens, J., \& Kroos, P. (2011). Target ratcheting and effort reduction. Journal of Accounting and Economics, 51 (1), 171-185. doi: 10.1016/ j.jacceco.2010.07.002

Bowen, H. (1943). The interpretation of voting in the allocation of economic resources. The Quarterly Journal of Economics, 58(1), 27-48. doi: 10.2307/1885754

Brennan, G., \& Buchanan, J. (1977). Towards a tax constitution for Leviathan. Journal of Public Economics, 8(3), 255-273. doi: 10.1016/0047 $-2727(77) 90001-9$

Brennan, G., \& Buchanan, J. (1978). Tax instruments as constraints on the disposition of public services. Journal of Public Economics, 9(3), 301-318. doi: 10.1016/0047-2727(78)90013-0

Dobell, P., \& Ulrich, M. (2002). Parliament's performance in the budget process: A case study. Policy Matters, 3(5), 1-24. Retrieved from https://irpp.org/ research-studies/policy-matters-vol3 -no5/

Dye, R. F., \& McGuire, T. J. (1997). The effect of property tax limitation measures on local government fiscal behavior. Journal of Public Economics, 66(3), 
469-487. doi: 10.1016/So047-2727 (97)00047-9

Freeman, R. J., \& Shoulders, C. D. (2003). Governmental and nonprofit accounting-theory and practice (2nd ed.). New Jersey: Prentice Hall.

Freixas, X., Guesnerie, R., \& Tirole, J. (1985). Planning under incomplete information and the ratchet effect. The $R e-$ view of Economic Studies, 52(2), 173191. doi: 10.2307/2297615

Gerber, E. R., \& Lewis, J. B. (2004). Beyond the median: voter preferences, district heterogeneity, and political representation. Journal of Political Economy, 112(6), 1364-1383. doi: $10.1086 / 424737$

Giroux, G., \& Shields, D. (1993). Accounting controls and bureaucratic strategies in municipal government. Journal of Accounting and Public Policy, 12(3), 239-262.

Government Regulation Number 58 of 2005 concerning The Local Government Financial Management (Peraturan Pemerintah Republik Indonesia Nomor 58 Tahun 2005 Tentang Pengelolaan Keuangan Daerah). Retrieved from http:// www.jdih.kemenkeu.go.id/ fullText/2005/58Tahun2005PP.HTM

Hercowitz, Z., \& Strawczynsky, M. (2002). Cyclical ratcheting in government spending: evidence form OECD. International Monetary Fund Working Paper, 1-30. Retrieved from https:// www.imf.org/external/pubs/ft/ wp/2004/wp04202.pdf

Hobson, J. L., Mellon, M. J., \& Stevens, D. E. (2011). Determinants of moral judgment regarding budgetary slack: an experimental examination of pay scheme and personal value. Behavioral Research in Accounting, 23(1), 87107. doi: 10.2308/bria.2011.23.1.87

Indjejikian, R. J., Matejka M., \& Schloetzer J. D. (2014) Target ratcheting and incentives: theory, evidence and new opportunities. The Accounting $R e$ view, 89(4), 1259-1267. doi: $10.2308 /$ accr-50745

Kim, D. S., \& Yang, J. (2012). Behind the scenes: performance target setting of annual incentive plans (December 7 , 2012). AFA 2010 Atlanta Meetings
Paper. doi: 10.2139/ssrn.1361814

Law Number 32 of 2004 concerning Local Government (Undang-Undang Republik Indonesia Nomor 32 Tahun 2004 Tentang Pemerintahan Daerah). Retrieved from https://www.dpr.go.id/ dokjdih/document/uu/33.pdf

Lee, T. M., \& Plummer, E. (2007). Budget adjustment in response to spending variance: evidence of ratcheting of local government expenditures. Journal of Management Accounting Research, 19 (1), 137-167. doi: 10.2308/ jmar.2007.19.1.137

Leone, A. J., \& Rock, S. (2002). Empirical test of budget ratcheting and its effect on managers' discretionary accrual choices. Journal of Accounting and Economics, 33(1), 43-67. doi: 10.1016/ S0165-4101(01)00044-1

McGuire, T. J. (1999). Proposition 13 and its offspring: for good or evil? National Tax Journal, 52, 129-138.

Ministry of Home Affairs Decree Number 29 of 2002 concerning Guidelines For Administration, Responsibility, and Supervision of Local Finances and Procedures for Forming The Local Budget, Implementation of Local Financial Administration and Local Budget Calculation (Keputusan Menteri Dalam Negeri Nomor 29 Tahun 2002 Tentang Pedoman Pengurusan, Pertanggungjawaban dan Pengawasan Keuangan Daerah Serta Tata Cara Penyusunan Anggaran Pendapatan dan Belanja Daerah, Pelaksanaan Tata Usaha Keuangan Daerah dan Penyusunan Perhitungan Anggaran Pendapatan dan Belanja Daerah). Retrieved from https:// palembang.bpk.go.id/?p=3297

Ministry of Home Affairs Regulation Number 13 of 2006 concerning Guidelines for Local Government's Financial Management (as amended by Number 53 of 2007 and Number 21 of 2011) (Peraturan Menteri Dalam Negeri Nomor 13 Tahun 2006 Tentang Pedoman Pengelolaan Keuangan Daerah). Retrieved from http:// hukum.unsrat.ac.id/men/ permendagri_13_2006.pdf

Rankin, F. W., Schwartz, S. T., \& Young, R. A. (2008). The effect of honesty and su- 
perior authority on budget proposal. The Accounting Review, 83(4), 10831099. doi: 10.2308/ accr.2008.83.4.1083

Rubin, I. S. (1993). The politics of public budgeting: getting and spending, borrowing and balancing (2nd ed). Chatham, NJ: Chatham House Publishers, Inc.

Ungureanu, M., \& Iancu, D. (2012). The economic analysis of bureaucracy and government growth. Theoretical and Applied Economics, 29(11), 59-74.

Weitzman, M. L. (1980). The ratchet principle and performance incentives. Bell Journal of Economics, 11(1), 302308.

Wills, D. T. (1995). Future implication of the reversion level in agenda-setter models. Economics Letters, 49, 435-440. 